\title{
BADANIE WYDAJNOŚCI WYBRANYCH SYSTEMÓW WIRTUALIZACJI
}

\begin{abstract}
Obecnie koncepcja wirtualizacji wkroczyła praktycznie do każdej dziedziny informatyki. Wzrost mocy obliczeniowej serwerów sprawił, że optymalne wykorzystanie ich zasobów stało się istotnym problemem. Celem artykułu jest scharakteryzowanie wybranych rozwiązań technologicznych umożliwiających wirtualizację fizycznych serwerów. W artykule przedstawiono wybrane oprogramowanie do wirtualizacji systemów, a następnie przedstawiono badanie ich wydajności.
\end{abstract}

Słowa kluczowe: wirtualizacja, hyperwizor, ESXi, Hyper-V, XenServer

\section{Wybrane oprogramowanie do wirtualizacji systemów}

Wirtualizacja polega na wydzieleniu w obrębie jednego fizycznego serwera wielu (od kilku, nawet do kilkuset) znacznie mniejszych środowisk wirtualnych, rozszerzającym potencjał pojedynczego środowiska. Umożliwia efektywniejsze wykorzystanie istniejących zasobów sprzętowych środowiska informatycznego poprzez dowolne (w ramach możliwości sprzętowych czy programowych oraz założeń projektowych) modyfikowanie cech wirtualizowanych zasobów, dostosowując je do indywidualnych wymagań użytkownika. Istnieje szereg rozwiązań programowych realizujących wirtualizację, np. VMware ESXi, Hyper-V, XenServer, które to kolejno zostały scharakteryzowane poniżej.

\subsection{VMware ESXi}

VMware (https://www.vmware.com/) to istniejący na rynku od 1998 roku lider komercyjnych rozwiązań wirtualizacji i producent wirtualizatora typu 1, Elastic Sky X integrated (ESXi). ESXi to główna część bogatego pakietu

${ }^{1}$ Autor do korespondencji: Przemysław Kałucki, adres e-mail: pakalucki@gmail.com

${ }^{2}$ Paweł Dymora, Politechnika Rzeszowska, Zakład Systemów Złożonych, pawel.dymora@prz.edu.pl

${ }^{3}$ Mirosław Mazurek, Politechnika Rzeszowska, Zakład Systemów Złożonych, miroslaw.mazurek@prz.edu.pl 
do wirtualizacji i rozwiązań w chmurze vSphere. Wirtualizator ten bazuje na linuxowym jądrze i jest instalowany jako bare-metal, czyli bezpośrednio na sprzęcie. Jądro ESXi bezpośrednio zarządza zasobami korzystając z techniki scan before execution, dzięki czemu może wychwycić i obsłużyć wrażliwe i niebezpieczne instrukcje systemów gości. Wirtualizator dodatkowo wykorzystuje parawirtualne sterowniki dla wirtualnych urządzeń i obsługi operacji wejścia/wyjścia co znacznie poprawia wydajność. Maszyny wirtualne $\mathrm{w}$ ESXi działają $\mathrm{z}$ wykorzystaniem wsparcia sprzętowego $\mathrm{z}$ dodatkiem parawirtualizowanych sterowników dla optymalizacji operacji wejścia/wyjścia. Wirtualizatorem można zarządzać przez sieć, łącząc się za pomocą aplikacji vSphere Client (aplikacja desktopowa) lub vSphere Web Client (aplikacja webowa). Dodatkowo istnieje oprogramowanie będące częścią pakietu vSphere o nazwie vCenter Server. Może być ono zainstalowane na fizycznej bądź wirtualnej maszynie z systemem Windows Server 2012 lub jako samodzielna maszyna wirtualna bazująca na jądrze Linuxa. vCenter Server zapewnia dużo większą kontrolę nad wirtualizatorem ESXi, jak i daje możliwość zarządzania siecią kilkunastu wirtualizatorów [1].

\subsection{Microsoft Hyper-V}

Wirtualizator Hyper-V (www.microsoft.com/pl-pl/cloud-platform/ virtualization) to istniejące na rynku od 2008 roku podejście do wirtualizacji firmy Microsoft. Może funkcjonować jako właściwość (ang. feature) doinstalowywana do systemów klasy Windows Server, Windows Pro i Enterprise (od wersji $8.1 \mathrm{w}$ górę) lub jako oddzielny produkt działający w trybie bare-metal. Do zarządzania Hyper-V wykorzystuje się cienkiego klienta Hyper-V Manager, który tak jak sam wirtualizator można dodać jako właściwość do wcześniej wspomnianych systemów z rodziny Windows. Ten wirtualizator stosuje izolację maszyn wirtualnych na zasadzie partycji. Systemy operacyjne gości działają $\mathrm{w}$ oddzielnych partycjach, zaś główne procesy wirtualizatora działają w osobnej, głównej partycji. Zbiór funkcji i zasobów wirtualizatora, inaczej stos wirtualizacyjny ma z głównej partycji bezpośredni dostęp do sterowników sprzętowych. Partycja użytkowa nie ma ani dostępu do procesora, ani nie obsługuje prawdziwych przerwań. Wirtualizator może udostępnić partycjom maszyn wirtualnych fragment procesora, dzięki temu, że sam obsługuje przerwania i odpowiednio przekierowuje je wykorzystując mechanizm SynIC (ang. Synthetic Interrupt Controller). Maszyny wirtualne stworzone w Hyper-V posiadają przegląd dostępnych zasobów i sprzętu w postaci wirtualnych urządzeń. Każdy sygnał do wirtualnego urządzenia jest przekierowywany przez logiczny kanał zwany VMBus do głównej partycji, a odpowiedź tą samą drogą z powrotem do maszyny wirtualnej. W obrębie głównej partycji działa Dostawca Usługi Wirtualizacji (ang. Virtualization 
Service Provider), który odpowiada za obsługę sygnałów otrzymanych od Konsumenta Usługi Wirtualizacji (ang. Virtualization Service Client) działającego w partycji użytkowej i zarządzającego sygnałami wysyłanymi przez maszyny wirtualne. Cały ten proces jest jawny dla systemu gościa. Całość opiera się na sprzętowym wsparciu wirtualizacji. Hyper-V 2016 jest oprogramowaniem komercyjnym $\mathrm{z}$ zamkniętymi źródłami, ale wersję samodzielną można za darmo pobrać ze strony producenta i użytkować, ciesząc się pełną funkcjonalnością [2-3].

\subsection{Citrix XenServer}

XenServer to projekt open source zarządzany przez firmę Citrix (http://xenserver.org/), dostarczający platformę do wirtualizacji bazującą na wirtualizatorze Xen. Xen zapoczątkowany był jako projekt naukowy w University of Cambridge, a pierwsze publiczne wydanie wirtualizatora Xen miało miejsce w 2003 roku. XenServer można za darmo pobrać ze strony produktu i używać w pełnej wersji. Dodatkowo istnieje możliwość rozszerzania platformy o funkcje i aplikacje produkowane przez firmy trzecie i innych użytkowników. Do zarządzania wirtualizatorem powstała aplikacja XenCenter przeznaczona na systemy Windows. Zarządzenie z innych systemów możliwe jest za pomocą innych aplikacji np. Xen Orchestra. Hyperwizor Xen to warstwa abstrakcji działająca bezpośrednio na sprzęcie, przed systemem operacyjnym. Oprócz zarządzania maszynami wirtualnymi jest dodatkowo odpowiedzialny za zarzadzanie procesorem i pamięcią operacyjną. Do działania całego środowiska konieczne jest funkcjonowanie maszyny wirtualnej zwanej Domain 0, w skrócie Dom0. Jest to automatycznie tworzona maszyna wirtualna zawierająca zmodyfikowane jądro systemu Linux, posiadająca specjalne prawa dostępu do fizycznych zasobów jak i możliwość interakcji z innymi maszynami wirtualnymi. Dom0 posiada dwa sterowniki Network Backend Driver i Block Backend Driver pozwalające jej na zarządzanie dostępnymi interfejsami sieciowymi i dyskami. Pod nazwą Domain $U$ kryje się przestrzeń, w której działają normalne maszyny wirtualne i ich systemy nie mające bezpośredniego dostępu do fizycznych zasobów. W Xen systemy gości mogą działać w trybie parawirtualizacji oraz $\mathrm{w}$ trybie pełnej wirtualizacji $\mathrm{z}$ wykorzystaniem wsparcia sprzętowego [4-6].

\section{Badanie wydajności i efektywności wybranych rozwiązań wirtualizacji}

\subsection{Oprogramowanie testowe}

Do wykonania testów wydajnościowych zdecydowano się na skorzystanie z narzędzia SiSoftware Sandra Lite (http://www.sisoftware.net/). Jest to 
popularna i darmowa wersja programu diagnostycznego dla komputerów z systemami z rodziny Windows, umożliwiająca uruchomienie kompleksowego zestawu testów sprawdzających wszystkie istotne elementy systemu. W celu sprawdzenia wydajności maszyn wirtualnych uruchomiono pakiet składający się z testów wymienionych w tabeli 1 [7].

Tabela 1. Pakiety testów wydajnościowych

Table 1. Performance testing packages

\begin{tabular}{|c|c|c|c|}
\hline Nazwa testu & Kategoria & Opis & Jednostka \\
\hline $\begin{array}{c}\text { Processor Multi- } \\
\text { Media }\end{array}$ & Procesor & $\begin{array}{c}\text { Wydajność jednostek Single } \\
\text { Instruction, Multiple Data } \\
\text { (SIMD). Im wyższy wynik tym } \\
\text { lepiej. }\end{array}$ & Mpix/s - MegaPixels Per Second \\
\hline $\begin{array}{c}\text { Processor } \\
\text { Cryptography }\end{array}$ & Procesor & $\begin{array}{c}\text { Wydajność operacji szyfrowania, } \\
\text { deszyfrowania i haszowania. Im } \\
\text { wyższy wynik tym lepiej. }\end{array}$ & GB/s - GigaBytes Per Second \\
\hline $\begin{array}{c}\text { Processor Financial } \\
\text { Analysis }\end{array}$ & Procesor & $\begin{array}{c}\text { Wydajność procesora } \\
\text { w przeprowadzaniu analizy } \\
\text { finansowej za pomocą } \\
\text { popularnych modeli. Im wyższy } \\
\text { wynik tym lepiej. }\end{array}$ & kOPT/s - Kilo Options Per \\
Second
\end{tabular}

\subsection{Metodologia badań}

Do sprawdzenia wydajności i możliwości użytkowych wirtualizatorów zdecydowano się na przeprowadzenie kilku scenariuszy testowych:

- uruchomienie zestawu testów na jednej maszynie wirtualnej, gdy wszystkie pozostałe maszyny są nieaktywne;

- uruchomienie zestawu testów na jednej maszynie wirtualnej, kiedy łącznie aktywnych jest kolejno 30, 20, 15 i 10 maszyn; 
- uruchomienie zestawu testów na wszystkich aktywnych maszynach w celu symulowania obciążenia, kolejno dla 30, 20, 15 i 10 maszyn.

Aby zmniejszyć wpływ błędu pomiaru na wyniki, wykonano 10 powtórzeń pomiarów dla każdego testu w każdym scenariuszu i obliczono średnie wyniki. Aktywna maszyna wirtualna oznacza, że dana maszyna jest uruchomiona i zakończył się proces inicjalizacji systemu operacyjnego. Za nieaktywną maszynę wirtualną uznaje się całkowicie wyłączoną maszynę. Na maszynach wirtualnych zainstalowano system Windows Server 2016. Do maszyn przydzielono zasoby $\mathrm{w}$ postaci 2 GB pamięci RAM oraz dwa wirtualne procesory. Dodatkowo maszyny działały jako połączone klony, dzieląc między sobą cześć plików systemowych i aplikacji [8].

\subsection{Analiza wyników dla ESXI}

Tabela 2 przedstawia średnie wyniki pomiarów uzyskane w testach wydajności maszyn wirtualnych w wirtualizatorze ESXi 6.5.0 dla scenariuszy testowych sprawdzających wydajność pojedynczej maszyny wirtualnej wraz ze zwiększającą się liczbą aktywnych łącznie maszyn, ale bez obciążania ich. Choć $\mathrm{w}$ teorii wirtualizator powinien dynamicznie alokować zasoby do maszyny wirtualnej, na której działa program przeprowadzający testy jako tej $\mathrm{z}$ największym zapotrzebowaniem i niwelować przez to spadek wydajności wynikający z braku zasobów, to jak widać wraz ze wzrostem liczby aktywnych maszyn, niewiele ale stopniowo pogarszają się też otrzymywane w testach wyniki, jednak nie dochodzi do sytuacji, w których obciążenie jest na tyle duże aby uniemożliwić płynne korzystanie z maszyn wirtualnych.

Tabela 2. Wyniki pomiarów dla ESXi bez obciążeń

Table 2. Data results for ESXi without load

\begin{tabular}{|l|c|c|c|c|c|c|}
\hline \multicolumn{1}{|c|}{$\begin{array}{c}\text { Liczba } \\
\text { maszyn }\end{array}$} & $\mathbf{1}$ & $\mathbf{1 ~ z ~ 1 0}$ & $\mathbf{1 ~ z ~ 1 5}$ & $\mathbf{1}$ z 20 & $\mathbf{1 ~ z ~ 3 0}$ & Jednostka \\
\hline Processor Multimedia & 83.272 & 82.633 & 82.621 & 82.406 & 82.112 & $\mathrm{Mpix} / \mathrm{s}$ \\
\hline Processor Cryptography & 2.982 & 2.899 & 2.888 & 2.868 & 2.814 & $\mathrm{~GB} / \mathrm{s}$ \\
\hline $\begin{array}{l}\text { Processor Financial } \\
\text { Analysis }\end{array}$ & 5.941 & 5.940 & 5.922 & 5.901 & 5.880 & $\mathrm{kOPT} / \mathrm{s}$ \\
\hline $\begin{array}{l}\text { Processor Scientific } \\
\text { Analysis }\end{array}$ & 13.655 & 13.622 & 13.424 & 13.378 & 13.311 & $\mathrm{GFLOPS}$ \\
\hline .NET Arithmetic & 9.830 & 9.171 & 9.021 & 8.888 & 8.599 & $\mathrm{GOPS}$ \\
\hline $\begin{array}{l}\text { Memory Bandwidth } \\
\text { Memory Latency }\end{array}$ & 23.763 & 23.753 & 22.166 & 16.911 & 14.908 & $\mathrm{~GB} / \mathrm{s}$ \\
\hline File System Bandwidth & 33.111 & 33.998 & 34.607 & 45.122 & 55.888 & $\mathrm{~ns}$ \\
\hline
\end{tabular}


W Tabeli 3 umieszczono średnie rezultaty testów wydajności maszyn wirtualnych w scenariuszach testowych wprowadzających element obciążenia poprzez uruchomienie programu testującego na wszystkich aktywnych maszynach wirtualnych, kolejno dla coraz większej liczby maszyn, aż do 30 . W tym przypadku już dla 28 maszyny można zaobserwować większe spadki w wydajności, a w ostatnim przypadku, kiedy aktywne i obciążone jest 30 maszyn wirtualnych można odczuć już problemy z płynnym użytkowaniem maszyn wirtualnych.

Tabela 3. Wyniki pomiarów dla ESXi z obciążeniem

Table 3. Data results for ESXi with load

\begin{tabular}{|c|c|c|c|c|c|}
\hline Nazwa testu $\longrightarrow \begin{array}{c}\text { Liczba } \\
\text { maszyn }\end{array}$ & 10 & 15 & 20 & 30 & Jednostka \\
\hline Processor Multimedia & 58.346 & 43.193 & 40.429 & 40.414 & Mpix/s \\
\hline Processor Cryptography & 1.639 & 1.293 & 1.098 & 0.995 & $\mathrm{~GB} / \mathrm{s}$ \\
\hline Processor Financial Analysis & 3.948 & 2.759 & 1.999 & 1.535 & $\mathrm{kOPT} / \mathrm{s}$ \\
\hline Processor Scientific Analysis & 5.365 & 3.859 & 3.376 & 2.472 & GFLOPS \\
\hline .NET Arithmetic & 6.530 & 4.699 & 3.631 & 2.644 & GOPS \\
\hline Memory Bandwidth & 18.049 & 14.141 & 14.161 & 7.176 & $\mathrm{~GB} / \mathrm{s}$ \\
\hline Memory Latency & 42.910 & 63.260 & 63.705 & 74.820 & ns \\
\hline File System Bandwidth & 1599.061 & 1184.148 & 1017.989 & 839.566 & $\mathrm{MB} / \mathrm{s}$ \\
\hline
\end{tabular}

\subsection{Analiza wyników dla Hyper-V}

Tabela 4 prezentuje średnie wyniki uzyskane w testach wydajnościowych przez maszyny wirtualne działające $\mathrm{w}$ wirtualnej pracowni komputerowej zaimplementowanej w wirtualizatorze Hyper-V 2016 w scenariuszu testowym bez dodatkowego obciążenia. Choć wirtualizator powinien dynamicznie rozdzielać zasoby między maszynami wirtualnymi, tak aby nie występowały spadki wydajności wynikające $\mathrm{z}$ braku zasobów (kiedy jedna z maszyn ma większe zapotrzebowanie niż pozostałe) to mimo tego można zaobserwować spadek wydajności wraz ze wzrostem liczby aktywnych maszyn. Warto zwrócić też uwagę na szczególnie dobry wynik uzyskiwany przez maszyny wirtualne w Hyper-V w teście File System Bandwidth sprawdzającym prędkość systemu plików i dysku. 
Tabela 4. Wyniki pomiarów dla Hyper-V bez obciążeń

Table 4. Data results for Hyper-V without load

\begin{tabular}{|l|c|c|c|c|c|c|}
\hline $\begin{array}{l}\text { Nazwa Testu Liczba } \\
\text { maszyn }\end{array}$ & $\mathbf{1}$ & $\mathbf{1 ~ z ~ 1 0}$ & $\mathbf{1 ~ z ~ 1 5}$ & $\mathbf{1}$ z 20 & $\mathbf{1 ~ z ~ 3 0}$ & Jednostka \\
\hline Processor Multimedia & 81.211 & 81.201 & 81.191 & 81.110 & 80.980 & $\mathrm{Mpix} / \mathrm{s}$ \\
\hline $\begin{array}{l}\text { Processor } \\
\text { Cryptography }\end{array}$ & 2.899 & 2.886 & 2.884 & 2.874 & 2.869 & $\mathrm{~GB} / \mathrm{s}$ \\
\hline $\begin{array}{l}\text { Processor Financial } \\
\text { Analysis }\end{array}$ & 5.870 & 5.844 & 5.822 & 5.818 & 5.811 & $\mathrm{kOPT} / \mathrm{s}$ \\
\hline $\begin{array}{l}\text { Processor Scientific } \\
\text { Analysis }\end{array}$ & 12.573 & 12.466 & 12.433 & 12.417 & 12.399 & $\mathrm{GFLOPS}$ \\
\hline .NET Arithmetic & 9.771 & 9.666 & 9.545 & 9.513 & 9.471 & $\mathrm{GOPS}$ \\
\hline Memory Bandwidth & 23.409 & 23.110 & 22.998 & 22.989 & 22.983 & $\mathrm{~GB} / \mathrm{s}$ \\
\hline Memory Latency & 31.633 & 32.211 & 32.134 & 32.101 & 32.033 & $\mathrm{~ns}$ \\
\hline File System Bandwidth & 4698.416 & 4567.512 & 4122.854 & 3889.899 & 3521.920 & $\mathrm{MB} / \mathrm{s}$ \\
\hline
\end{tabular}

W Tabeli 5 zaprezentowano rezultaty testów przeprowadzonych na maszynach wirtualnych w Hyper-V, w warunkach ze zwiększonym obciążeniem. Jak można się spodziewać w tym przypadku odnotowano już większe spadki wydajności we wszystkich testach. Ostatni z testów, dotyczący dysku i systemu plików wyprodukował znacznie lepsze wyniki, niż w innych sprawdzanych wirtualizatorach.

Tabela 5. Wyniki pomiarów dla Hyper-V z obciążeniem

Table 5. Data results for Hyper-V with load

\begin{tabular}{|c|c|c|c|c|c|}
\hline Nazwa Testu $\quad \begin{array}{r}\text { Liczba } \\
\text { maszyn }\end{array}$ & 10 & 15 & 20 & 30 & Jednostka \\
\hline Processor Multimedia & 57.648 & 44.156 & 34.980 & 25.906 & Mpix/s \\
\hline Processor Cryptography & 1.772 & 1.294 & 1.024 & 0.848 & $\mathrm{~GB} / \mathrm{s}$ \\
\hline Processor Financial Analysis & 3.819 & 2.714 & 2.018 & 1.332 & $\mathrm{kOPT} / \mathrm{s}$ \\
\hline Processor Scientific Analysis & 5.315 & 3.828 & 2.875 & 2.213 & GFLOPS \\
\hline .NET Arithmetic & 6.437 & 4.669 & 3.480 & 2.638 & GOPS \\
\hline Memory Bandwidth & 20.712 & 20.023 & 13.798 & 11.036 & $\mathrm{~GB} / \mathrm{s}$ \\
\hline Memory Latency & 37.080 & 42.967 & 46.865 & 61.153 & $\mathrm{~ns}$ \\
\hline File System Bandwidth & 4343.215 & 4003.142 & 3844.297 & 2296.898 & $\mathrm{MB} / \mathrm{s}$ \\
\hline
\end{tabular}




\subsection{Analiza wyników dla XenServer}

Tabela 6 prezentuje rezultaty testów wydajnościowych, w których nie symulowano obciążenia dla maszyn wirtualnych $\mathrm{w}$ środowisku zaimplementowanym z wykorzystaniem wirtualizatora XenServer. W tym przypadku, dla scenariuszy $\mathrm{z}$ mniejszą liczbą aktywnych maszyn wirtualnych można zaobserwować wysokie wyniki w testach sprawdzających wydajność procesora, jednak wraz ze wzrostem liczby aktywnych maszyn osiągane wyniki szybko ulegają pogorszeniu.

Tabela 6. Wyniki pomiarów dla XenServer bez obciążenia

Table 6. Data results for XenServer without load

\begin{tabular}{|l|c|c|c|c|c|c|}
\hline \multicolumn{1}{|c|}{$\begin{array}{c}\text { Liczba } \\
\text { Mazwa testun }\end{array}$} & $\mathbf{1}$ & $\mathbf{1 ~ z ~ 1 0}$ & $\mathbf{1 ~ z ~ 1 5}$ & $\mathbf{1 ~ z ~ 2 0}$ & $\mathbf{1 ~ z ~ 3 0}$ & Jednostka \\
\hline Processor Multimedia & 100.520 & 98.510 & 96.501 & 88.767 & 88.440 & $\mathrm{Mpix} / \mathrm{s}$ \\
\hline Processor Cryptography & 3.994 & 3.579 & 3.163 & 3.101 & 2.985 & $\mathrm{~GB} / \mathrm{s}$ \\
\hline $\begin{array}{l}\text { Processor Financial } \\
\text { Analysis }\end{array}$ & 7.280 & 7.170 & 7.060 & 6.999 & 6.480 & $\mathrm{kOPT} / \mathrm{s}$ \\
\hline $\begin{array}{l}\text { Processor Scientific } \\
\text { Analysis }\end{array}$ & 15.730 & 14.745 & 13.760 & 13.430 & 13.250 & GFLOPS \\
\hline .NET Arithmetic & 10.960 & 10.465 & 9.970 & 8.410 & 8.260 & $\mathrm{GOPS}$ \\
\hline Memory Bandwidth & 14.523 & 14.247 & 13.970 & 13.968 & 12.151 & $\mathrm{~GB} / \mathrm{s}$ \\
\hline Memory Latency & 39.910 & 40.360 & 40.777 & 41.623 & 42.414 & $\mathrm{~ns}$ \\
\hline File System Bandwidth & 1327.855 & 1288.780 & 1259.705 & 1250.330 & 1241.380 & $\mathrm{MB} / \mathrm{s}$ \\
\hline
\end{tabular}

Tabela 7. Wyniki pomiarów dla XenServer z obciążeniem

Table 7. Data results for XenServer with load

\begin{tabular}{|l|c|c|c|c|c|}
\hline $\begin{array}{r}\text { Liczba } \\
\text { maszyn }\end{array}$ & $\mathbf{1 0}$ & $\mathbf{1 5}$ & $\mathbf{2 0}$ & $\mathbf{3 0}$ & Jednostka \\
\hline Processor Multimedia & 61.280 & 49.592 & 38.541 & 28.041 & $\mathrm{Mpix} / \mathrm{s}$ \\
\hline Processor Cryptography & 1.065 & 0.851 & 0.674 & 0.536 & $\mathrm{~GB} / \mathrm{s}$ \\
\hline Processor Financial Analysis & 4.007 & 2.684 & 2.042 & 1.340 & $\mathrm{kOPT} / \mathrm{s}$ \\
\hline Processor Scientific Analysis & 3.830 & 3.177 & 2.205 & 1.890 & $\mathrm{GFLOPS}$ \\
\hline .NET Arithmetic & 6.247 & 4.664 & 3.407 & 2.412 & $\mathrm{GOPS}$ \\
\hline Memory Bandwidth & 5.451 & 5.134 & 3.984 & 3.864 & $\mathrm{~GB} / \mathrm{s}$ \\
\hline Memory Latency & 77.720 & 95.200 & 144.825 & 158.540 & $\mathrm{~ns}$ \\
\hline File System Bandwidth & 709.070 & 425.858 & 246.361 & 156.107 & $\mathrm{MB} / \mathrm{s}$ \\
\hline
\end{tabular}


Rezultaty testów wydajnościowych w XenServer przedstawiono w Tabeli 7. Wprowadzono obciążenie poprzez uruchamianie programu testującego na coraz większej liczbie maszyn jednocześnie. $\mathrm{Z}$ otrzymanych wyników wynika, że powyżej progu 15 aktywnych i obciążonych maszyn wirtualnych, XenServer zaczyna osiągać wyraźnie gorsze wyniki niż pozostałe wirtualizatory, a w ostatnim przypadku, dla 30 równocześnie pracujących maszyn wirtualnych trudno jest wykonywać operacje w systemie gościa maszyn wirtualnych ze względu na opóźnienie.

\subsection{Analiza porównawcza rezultatów symulacji}

$\mathrm{Na}$ rysunku 1. przedstawiono rezultaty uzyskane przez wszystkie testowane wirtualizatory w teście Processor Multimedia, który sprawdza wydajność jednostek SIMD (ang. Single Instruction Multiple Data) procesora poprzez generowanie zestawu fraktali i przedstawia zdolność procesora do obsługi instrukcji związanych z danymi i instrukcjami występującymi podczas obróbki grafiki [7]. W otrzymanych wynikach można zaobserwować wyraźną przewagę wirtualizatora XenServer, aż do testu dla 20 i 30 maszyn wirtualnych, gdzie wyraźnie przestaje radzić sobie z obciążeniem i najlepsze wyniki zaczyna uzyskiwać ESXi. Wirtualizatory ESXi, Hyper-V i XenServer w tym teście odnotowały kolejno $51.467 \%$, $68.100 \%$ i $72.103 \%$ spadek wydajności pomiędzy testem przy najmniejszym obciążeniu a największym.

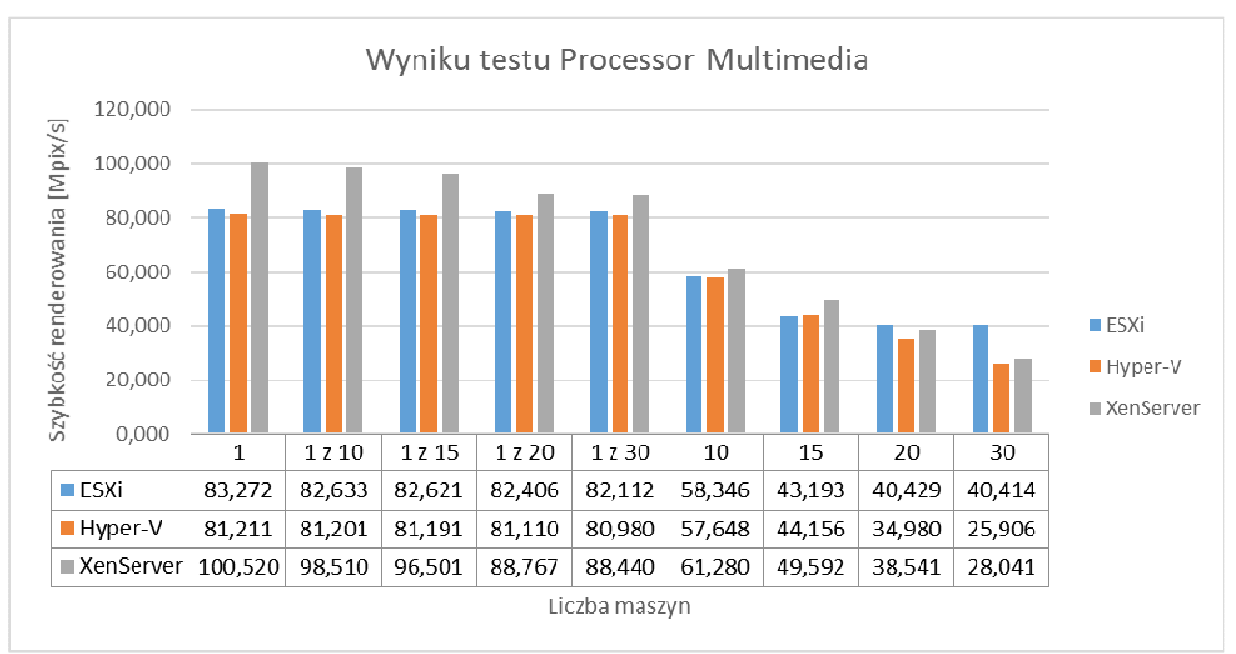

Rys. 1. Wyniki testu Processor Multimedia

Fig. 1. The results of the Processor Multimedia test

Rysunek 2. przedstawia rezultaty testu Processor Cryptography, który mierzy wydajność procesora $\mathrm{w}$ przeprowadzaniu typowych operacji wykonywanych na 
wrażliwych danych takich jak szyfrowanie, deszyfrowanie i haszowane danych używając algorytmów typu AES (ang. Advanced Encryption Standard) i SHA (ang. Secure Hash Algorithm) [7]. Tak jak we wcześniejszym teście najlepsze wyniki początkowo osiąga XenServer, wyraźnie tracąc prowadzenie wraz ze wzrostem obciążenia na rzecz ESXi i Hyper-V. Wirtualizatory ESXi, Hyper-V i XenServer w tym teście odnotowały kolejno $66.633 \%, 70.749 \%$ i $86.580 \%$ spadek wydajności pomiędzy testem przy najmniejszym obciążeniu a największym.

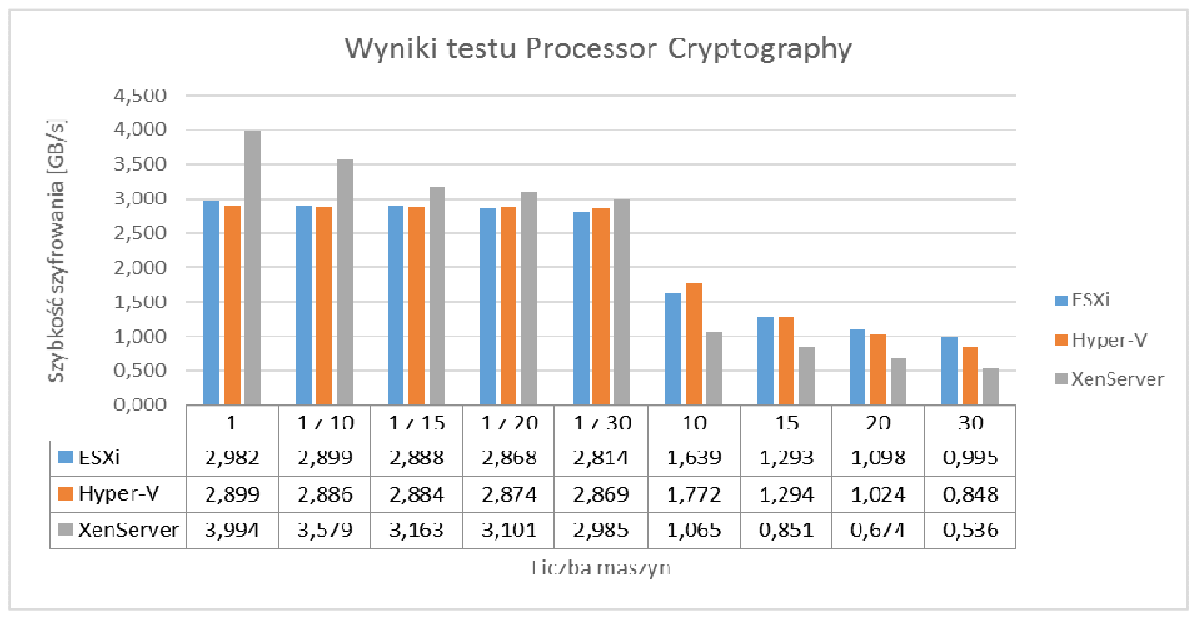

Rys. 2. Wyniki testu Processor Cryptography

Fig. 2. The results of the Processor Cryptography test

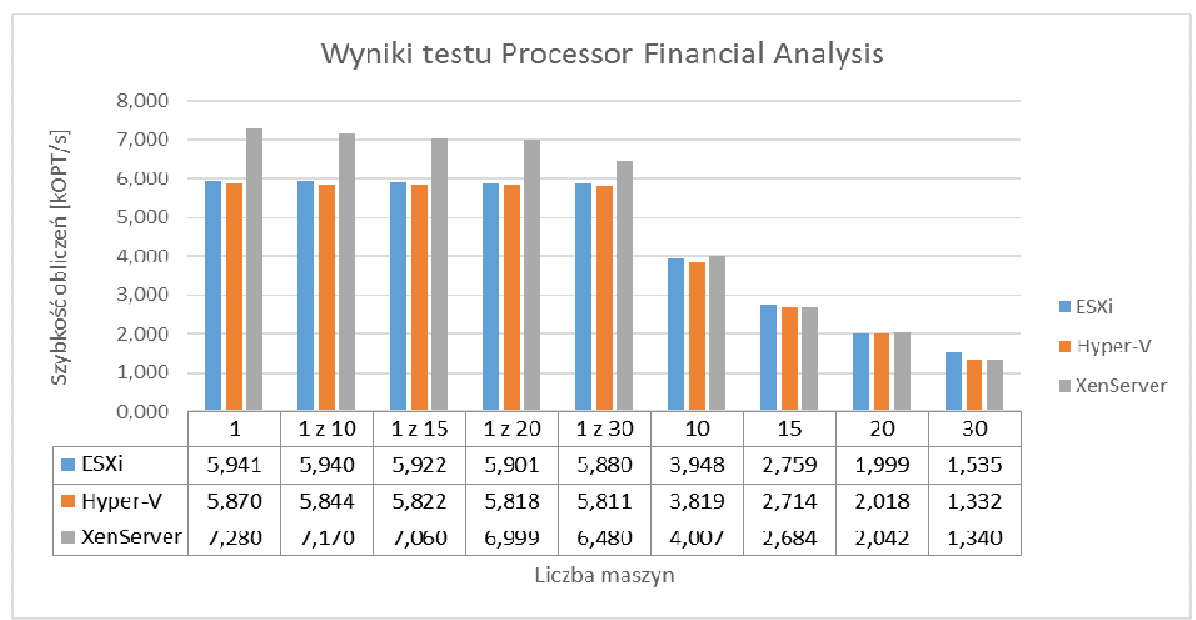

Rys. 3. Wyniki testu Processor Financial Analysis

Fig. 3. The results of the Processor Financial Analysis test 
$\mathrm{Na}$ rysunku 3. przedstawiono porównanie rezultatów osiągniętych przez testowane wirtualizatory w kolejnych scenariuszach testowych w teście Processor Financial Analysis, który polega na sprawdzeniu wydajności procesora bazując na tym jak efektywnie wykonuje obliczenia $\mathrm{z}$ wykorzystaniem popularnych modeli stosowanych w finansach do określania przyszłej wartości akcji [7]. Przy mniejszym obciążeniu wirtualizator XenServer osiąga najlepsze wyniki. Wraz ze wzrostem obciążenia wirtualizatory zaczynają osiągać zbliżone wyniki, z niewielką przewagą dla ESXi. Wirtualizatory ESXi, Hyper-V i XenServer w tym teście odnotowały kolejno $74.163 \%, 77.308 \%$ i $81.593 \%$ spadek wydajności pomiędzy testem przy najmniejszym obciążeniu a największym.

Wykres widoczny na rys. 4. przedstawia wyniki testu Processor Scientific Analysis, który mierzy wydajność procesora w wykonywaniu obliczeń takich jak operacje na macierzach czy transformata Fouriera [7]. Dla najmniejszego obciążenia najlepsze wyniki osiąga XenServer, a następnie ESXi. Wraz ze wzrostem obciążenia wydajność wirtualizatora XenServer wyraźnie spada, a ESXi osiąga nieznacznie lepsze wyniki niż Hyper-V. Wirtualizatory ESXi, Hyper-V i XenServer w tym teście odnotowały kolejno $81.897 \%, 82.399 \%$ i $87.985 \%$ spadek wydajności pomiędzy testem przy najmniejszym obciążeniu, a największym.

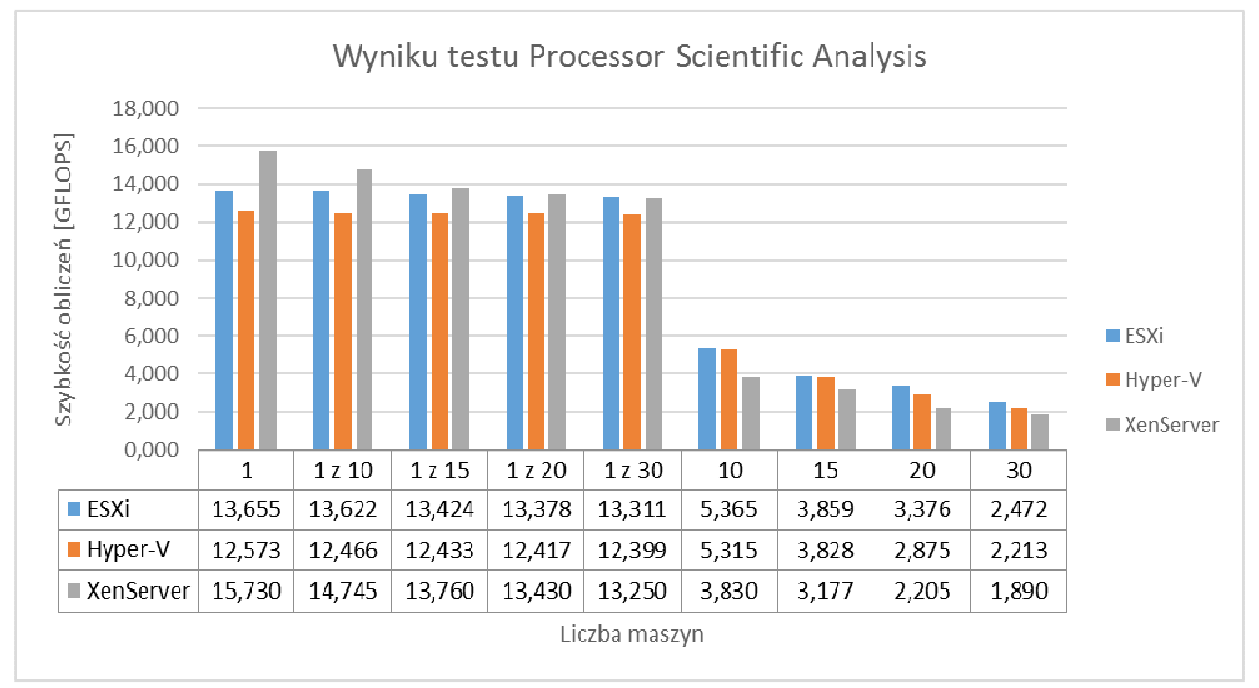

Rys. 4. Wyniki testu Processor Scientific Analysis

Fig. 4. The results of the Processor Scientific Analysis test

Test .NET Arithmetic, którego wyniki przedstawiono na rys. 5., mierzy wydajność wykonywania operacji arytmetycznych w frameworku .NET [7]. W tym przypadku dla testów przy najmniejszym obciążeniu najlepsze wyniki 
uzyskuje XenServer z wyjątkiem dla testu przy 1 z 20 i 1 z 30 maszyn wirtualnych, gdzie góruje Hyper-V. Wirtualizatory ESXi, Hyper-V i XenServer w tym teście zanotowały kolejno $73.103 \%, 73.002 \%$ i $77.993 \%$ spadek wydajności pomiędzy testem przy najmniejszym obciążeniu a największym.

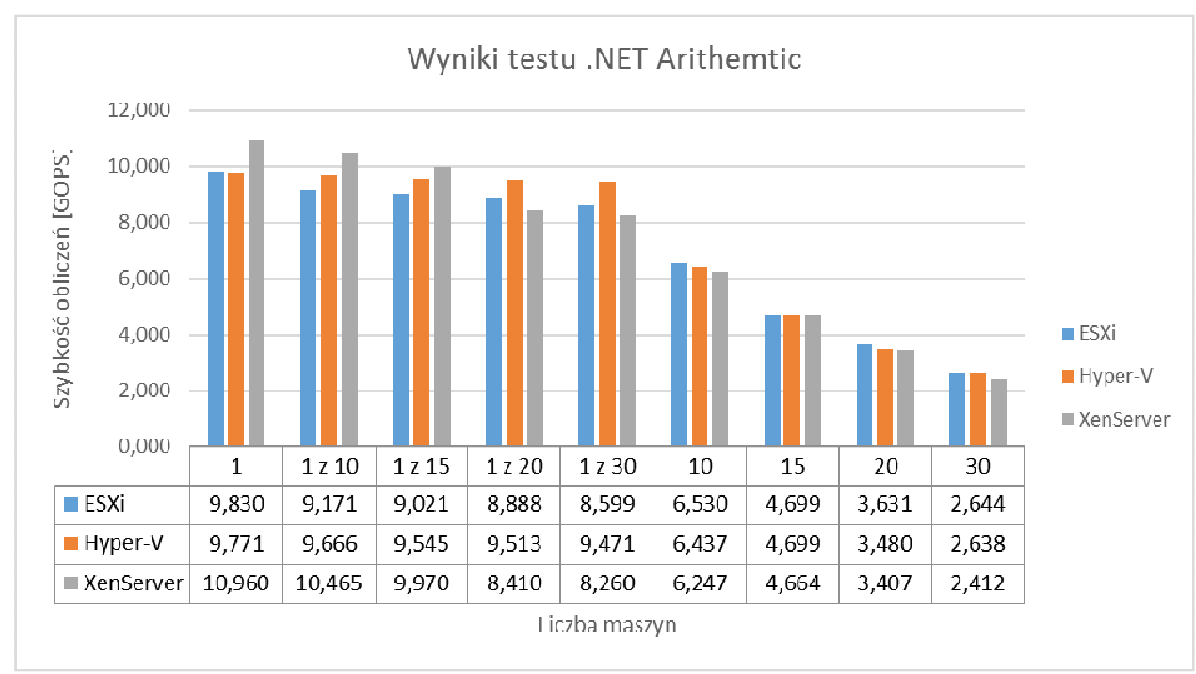

Rys. 5. Wyniki testu .NET Arithmetic

Fig. 5. The results of the .NET Arithmetic test

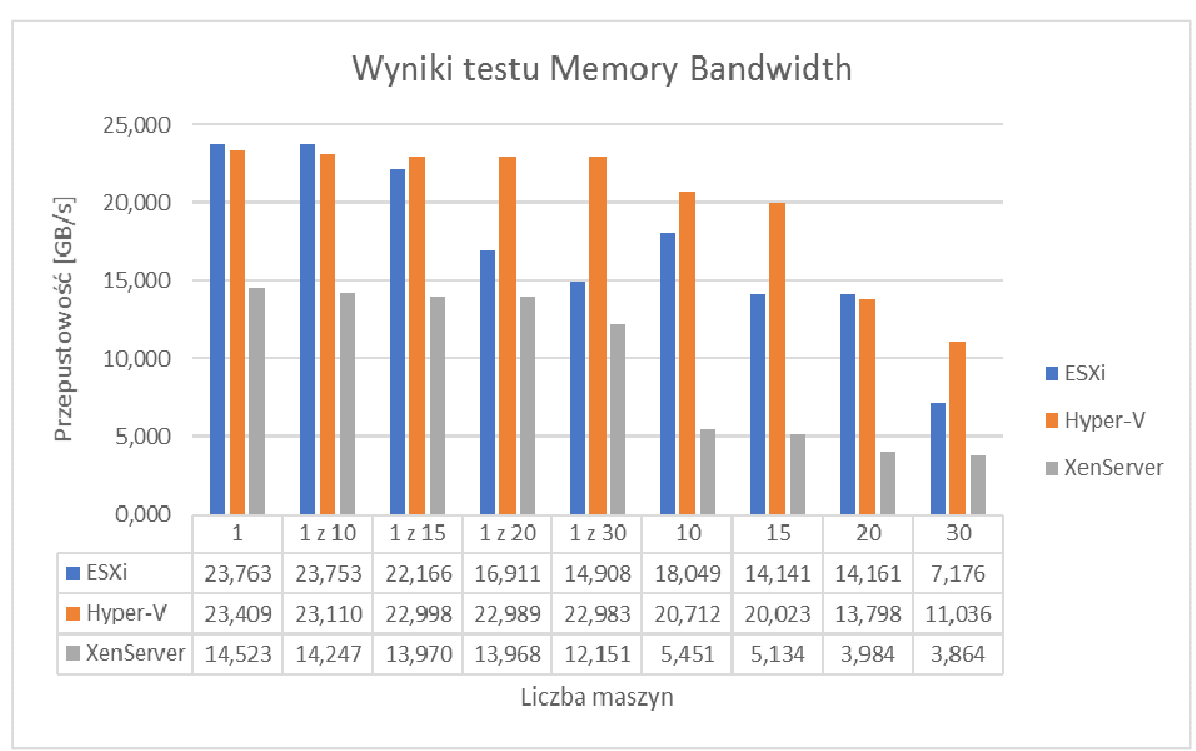

Rys. 6. Wyniki testu Memory Bandwidth

Fig. 6. The results of the Memory Bandwidth test 
Test Memory Bandwidth, przedstawiony na rys. 6. czyli test przepustowości pamięci operacyjnej bazuje na popularnym benchmarku STREAM [7]. Dla tego testu najlepsze wyniki zaobserwowano dla wirtualizatorów ESXi i Hyper-V. Wraz ze wzrostem obciążenia wyraźnie lepsze wyniki zachowuje Hyper-V. Warto też zauważyć, że ESXi lepiej radzi sobie z mniejszą liczbą obciążonych maszyn niż większą działających bez obciążenia, porównując wynik dla testu 1 z 20 czy 1 z 30 do testu dla 10 i 15 maszyn. Wirtualizatory ESXi, Hyper-V i XenServer w tym teście odnotowały kolejno $69.802 \%, 52.856 \%$ i $73.394 \%$ spadek wydajności pomiędzy testem przy najmniejszym obciążeniu a największym.

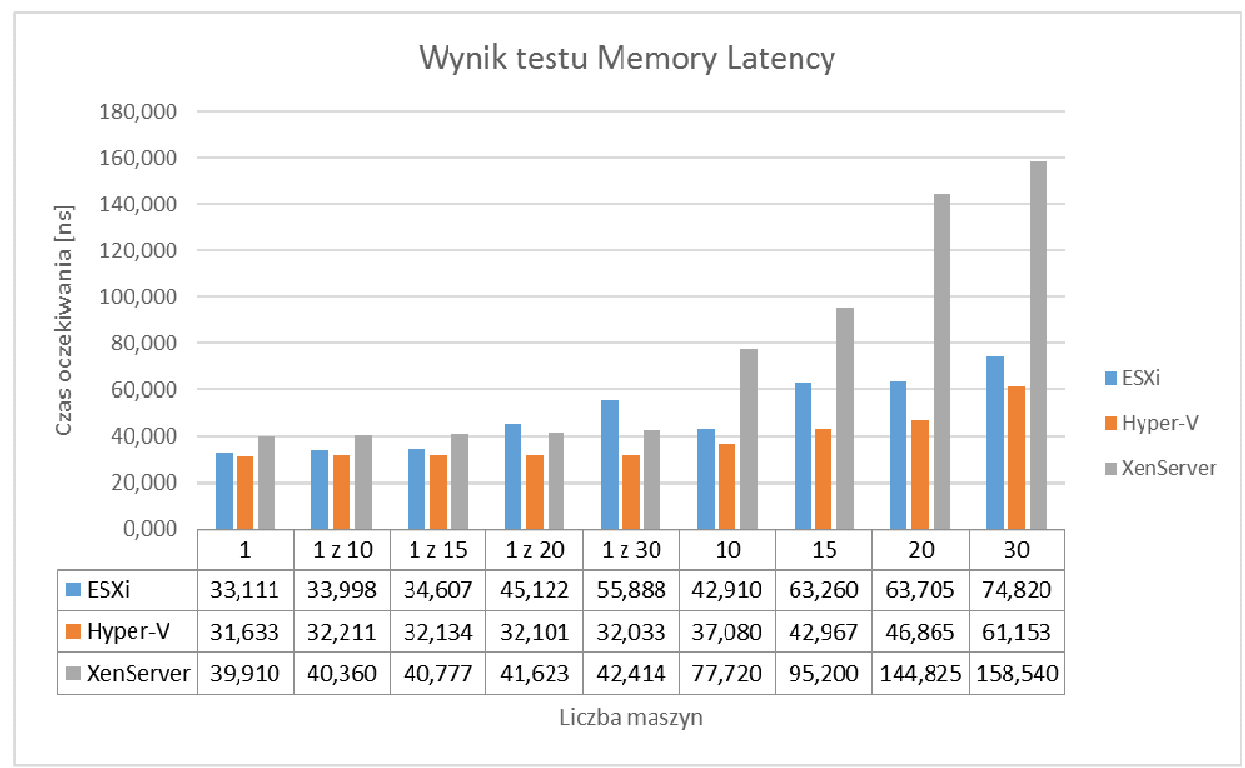

Rys. 7. Wyniki testu Memory latency

Fig. 7. The results of the Memory Latency test

Test Memory Latency, którego wyniki można zaobserwować na rys. 7 . obrazuje czas odpowiedzi pamięci operacyjnej jako czas w nanosekundach potrzebny na uzyskanie danych z pamięci [7]. W każdym przypadku można zaobserwować, że najlepszy wynik uzyskuje Hyper-V, a następnie ESXi. XenServer odczuwa znaczny spadek wydajności wraz ze wzrostem obciążenia. Tak jak w poprzednim teście pamięci ESXi lepiej radzi sobie z mniejszą liczbą obciążonych maszyn niż $\mathrm{z}$ większą liczbą mniej obciążonych maszyn, w przeciwieństwie do reszty wirtualizatorów. Wirtualizatory ESXi, Hyper-V i XenServer w tym teście zanotowały kolejno $55.746 \%$, $48.272 \%$ i $74.827 \%$ spadek wydajności pomiędzy testem przy najmniejszym obciążeniu, a największym. 


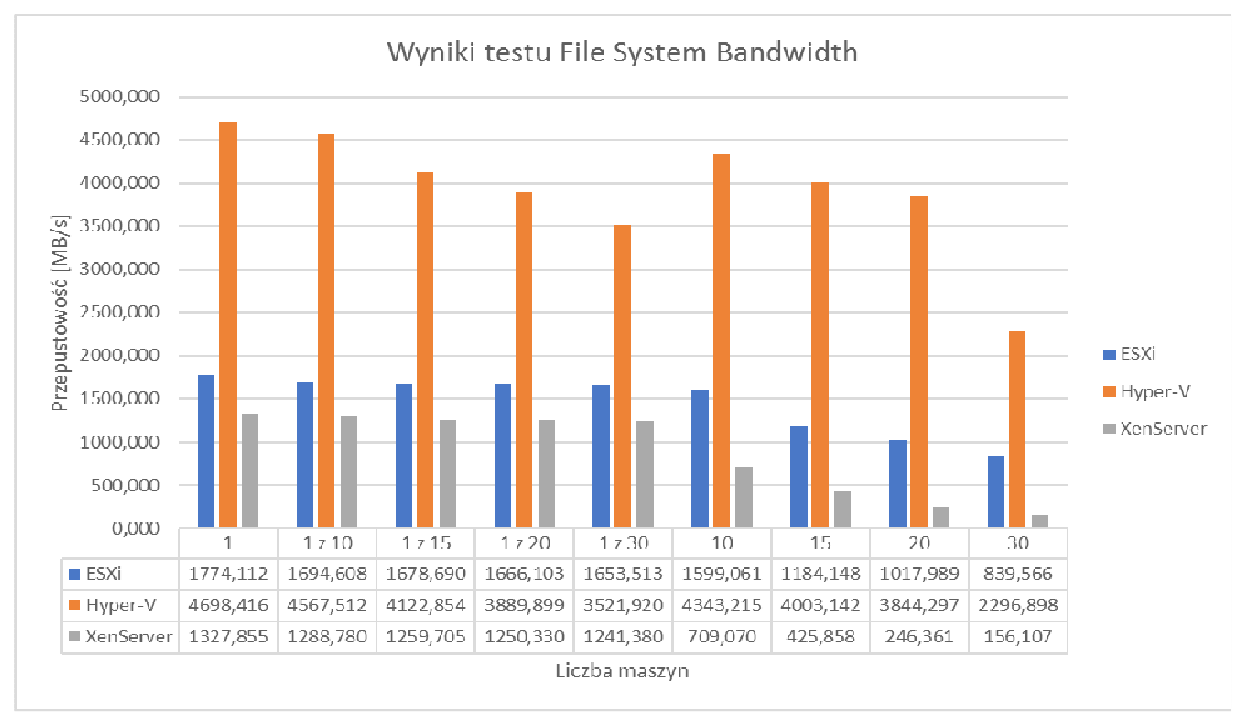

Rys. 8. Wyniki testu File System Bandwidth

Fig. 8. The results of the File System Bandwidth test

Test File System Bandwidth, którego wyniki przedstawia rys. 8., czyli test przepustowości systemu plików pokazuje wydajność operacji na dysku. Nie jest to wynik zależny wyłącznie od prędkości dysku, ale też od różnych czynników jak m.in. system plików, cache systemu operacyjnego czy pozycja dysku [7]. W tym teście znacznie lepsze wyniki uzyskuje wirtualizator Hyper-V, dodatkowo można zauważyć, że obciążenie ma w większości przypadków znacznie mniejszy wpływ na przepustowość systemu plików w Hyper-V i wirtualizator lepiej radzi sobie z mniejszą ilością obciążonych maszyn niż z większą ilością mniej obciążonych maszyn. Drugi w kolejności jest ESXi, natomiast najsłabsze wyniki osiąga XenServer. Wirtualizatory ESXi, Hyper-V i XenServer w tym teście odnotowały kolejno $52.677 \%, 51.113 \%$ i $88.244 \%$ spadek wydajności pomiędzy testem przy najmniejszym obciążeniu, a największym.

\section{Podsumowanie}

Przeprowadzone dla poszczególnych wirtualizatorów testy wydajności oraz porównanie oferowanych funkcjonalności wykazały, że ESXi firmy VMWare oferuje $\mathrm{w}$ większości przypadków najstabilniejsze rezultaty przy zwiększającym się obciążeniu. Dodatkową kwestię, którą można poruszyć w tym porównaniu to dużo bogatszy od konkurencji pakiet funkcjonalności i opcji konfiguracji. Wadą tego rozwiązania jest konieczność zakupu licencji. 
Kolejny wirtualizator, czyli Hyper-V firmy Microsoft osiągał porównywalne lub lepsze wyniki w testach wydajności (znacznie lepsze w testach dysku) jednak wyraźnie przeznaczony jest do działania w środowisku, gdzie wykorzystywane są tylko rozwiązania firmy Microsoft i w porównaniu do reszty ma ograniczoną funkcjonalność i jest trudniejszy w konfiguracji.

Ostatni z testowanych wirtualizatorów, jedyny reprezentant wolnego programowania, XenServer wyraźnie lepiej radził sobie z wirtualizacją operacji procesora przy niższych obciążeniach i choć natywnie nie oferuje tak wielu funkcjonalności jak ESXi, to ze względu na otwarte źródła i dużą, aktywną społeczność tworzącą rozszerzenia i ulepszenia, potencjalna możliwość rozbudowy i dostosowywania tego rozwiązania do własnych potrzeb jest ogromna.

\section{Literatura}

[1] http://www.vmware.com/products/vsphere-hypervisor.html, [dostęp: 10.12.2016].

[2] https://hyperv.veeam.com/blog/what-is-hyper-v-technology/, [dostęp: 10.12.2016].

[3] https://technet.microsoft.com/windows-server-docs/compute/hyper-v/hypervtechnology-overview, [dostęp: 10.12.2016].

[4] http://xenserver.org/, [dostęp: 10.12.2016].

[5] http://www-archive.xenproject.org/files/Marketing/HowDoesXenWork.pdf, [dostęp: 10.12.2016].

[6] Chris Takemura, Luke S. Crawford, The Book of Xen, NoStart Press 2010.

[7] Dokumentacja programu SiSoftware Sandra Lite

[8] https://www.vmware.com/support/ws5/doc/ws_clone_overview.html, [dostęp: 01.01.2017].

\section{VIRTUALIZATION OF INFORMATION SYSTEMS}

\section{S u m m a r y}

Nowadays concept of virtualization is common technology in almost every information technology based discipline. As the processing power of servers rise, it turns out that optimal use of available resources becomes meaningful issue. The purpose of this article is to summarize a few chosen virtualization platforms available for server virtualization. At the beginning, selected hypervisors and theirs characteristics are roughly described. Afterwards, results of overall performance tests inside environments implementing mentioned before hypervisors are presented and analyzed.

Keywords: virtualization, hypervisor, ESXi, Hyper-V, XenServer

DOI: $10.7862 /$ re.2017.11

Tekst złożono $w$ redakcji: wrzesień 2017

Przyjęto do druku: październik 2017 
